\title{
Electron attachment to the dipepetide dialanine: Influence of methylation on site selective dissociation reactions
}

\author{
Benjamin Puschnigg ${ }^{1}$, Stefan E. Huber ${ }^{1}$, Michael Probst ${ }^{1}$, ${\text { Katrin } \text { Tanzer }^{1} \text {, Violaine Vizcaino }}^{1}$, \\ Filipe Ferreira da Silva ${ }^{2}$, Paul Scheier ${ }^{1}$, Paulo Limão-Vieira ${ }^{2, *}$ and Stephan Denifl ${ }^{1, *}$ \\ ${ }^{1}$ Institut für Ionenphysik und Angewandte Physik and Center of Molecular Biosciences Innsbruck, \\ Universität Innsbruck, Technikerstr. 25, A-6020 Innsbruck, Austria \\ ${ }^{2}$ Laboratório de Colisões Atómicas e Moleculares, CEFITEC, Departamento de Física, Faculdade de \\ Ciências e Tecnologia, Universidade Nova de Lisboa, 2829-516 Caparica, Portugal
}

\begin{abstract}
Gas phase dissociative electron attachment (DEA) measurements with methyl-dialanine, $\mathrm{C}_{7} \mathrm{H}_{14} \mathrm{~N}_{2} \mathrm{O}_{3}$, are performed in a crossed electron-molecular beam experiment at high energy resolution $(\sim 120 \mathrm{meV})$. Anion efficiency yields as a function of the incident electron energy are obtained for the most abundant fragments up to electron energies of $\sim 15 \mathrm{eV}$. There is no evidence of molecular anion formation whereas the dehydrogenated closed shell anion (M$\mathrm{H})^{-}$is one of the most dominant reaction products. Quantum chemical calculations are performed to investigate the electron attachment process and to elucidate site selective bond cleavages in the $(\mathrm{M}-\mathrm{H})^{-}$DEA-channel. Previous DEA studies on dialanine have shown that $(\mathrm{M}-\mathrm{H})^{-}$formation proceeds through abstraction of a hydrogen atom from the carboxyl and amide groups, contributing with two distinct resonances at 0.81 and $1.17 \mathrm{eV}$, respectively [D. Gschliesser, V. Vizcaino, M. Probst, P. Scheier, and S. Denifl, Chem. Eur. J., 2012, 18, 46134619]. Here we show that by methylation of the carboxyl group all (calculated) thresholds for $\mathrm{H}$-loss from the different sites in the dialanine molecule are shifted up to a maximum of 1.4 $\mathrm{eV}$. The lowest lying resonance observed experimentally for $(\mathrm{M}-\mathrm{H})^{-}$remains operative from the amide group at the electron energy of $2.4 \mathrm{eV}$ due to the methylation. We further study methylation induced effects on the unimolecular dissociation leading to a variety of negatively charged DEA products.
\end{abstract}


*Corresponding authors. Email addresses: Stephan.Denifl@uibk.ac.at (Stephan Denifl); plimaovieira@fct.unl.pt (Paulo Limão-Vieira) 


\section{Introduction}

During the last decade, initiated by the pioneering work on electron induced damage to DNA, ${ }^{1}$ a broad set of experimental and computational dissociative electron attachment studies on biological relevant molecules have provided detailed information on the mechanisms underlying the deposition of the energy of the captured electron into these molecules and molecular networks. ${ }^{2,3}$. The nature of the biological degradation and its consequences (e.g. strand breaks that may lead to biological apoptosis) triggered by low-energy electrons, even at sub-excitation energies, ${ }^{4,5}$ has been thoroughly explained in reactions proceeding via formation of a transient negative ion (TNI). The TNI which is formed with an excess of internal energy decays either through the available dissociative channels or by electron ejection (autodetachment).

Amino acids have also attracted considerable attention due to their role as key subunits of proteins and as intermediates in the metabolism of cells. In fact, as some of the proteins' components intercalate within the DNA grooves, they may directly interact with the DNA building blocks. As such, mechanisms leading to fragmentation of proteins may result in the formation of reactive species that in the vicinity of DNA may induce structural (irreversible) damage. Understanding such processes from the radiobiological point of view turns out to be particularly relevant during the early stages of irradiation. Moreover, peptides are characterized by $\mathrm{OC}-\mathrm{NH}$ bonds formed from adjacent amino acids. Investigations based on dipeptides may provide relevant information from which already an understanding of the decomposition by ionizing radiation and subsequently formed low-energy electrons is possible. The resonant formation of negative ions in bare amino acid molecules ${ }^{6-15}$ and clusters embedded in helium droplets ${ }^{16-18}$ as well as in some dipeptides ${ }^{19-22}$ by free electrons has deserved considerable attention. We also note that negative ion formation by electron transfer in a crossed beam experiment has been studied in collisions of potassium atoms with glycine $^{23}$ in order to mimic a solvated state of an electron and complementing the studies with ballistic electrons. $^{24}$

Recently we carried out a detailed low-energy electron attachment study to the dipeptide dialanine. ${ }^{19,20}$ The molecule decomposes strongly upon capture of a low-energy electron which leads to a number of fragment anions and corresponding neutrals. The formation of the dehydrogenated parent anion turned out to be a particularly intense reaction channel and highly site selective as a function of the initial electron energy. The corresponding loss of a hydrogen atom from the molecule was assigned to the amide group and the carboxyl group. In the present work we investigate the negative ion formation from the dipeptide methyl- 
dialanine (see Figure 1a for the corresponding molecular structure), where in contrast to native dialanine the hydrogen at the carboxyl group is replaced by a methyl group. DEA in the electron energy range from $\sim 0$ up to $15 \mathrm{eV}$ is investigated by recording the ion yield curves with high energy resolution $(\sim 120 \mathrm{meV})$ utilizing an electron monochromator. Abundant fragment anion signal is due to $(\mathrm{M}-\mathrm{H})^{-} / \mathrm{C}_{7} \mathrm{H}_{13} \mathrm{~N}_{2} \mathrm{O}_{3}{ }^{-}$formation, and in addition a variety of other DEA products are formed.

\section{Experimental Setup}

Electron attachment to methyl-dialanine was investigated by means of a crossed electronmolecular beam set-up which has been described in detail elsewhere. ${ }^{25}$ Briefly, a high resolution electron beam (full width at half maximum (FWHM) of about $120 \mathrm{meV}$ ) is formed in a hemispherical electron monochromator with typical currents of $\sim 10 \mathrm{nA}$. Negative ions formed in the interaction region are extracted by weak electric fields, mass analyzed by means of a quadrupole mass filter and detected in a channel electron multiplier operated in pulse counting mode. The time window from the anion formation to its detection is in the order of about 100 microseconds. Negative ion yields of mass-selected anions are obtained as a function of the electron energy. Methyl-dialanine was purchased from Ukrorgsyntez, Riga, Latvia, and has a stated purity of $95 \%$. The sample is solid at room temperature and has to be heated in order to increase its vapour pressure, so that at moderately elevated temperatures an effusive molecular beam can be generated. The effusive molecular beam emerges through a capillary from a heated oven operated at a temperature of around $380 \mathrm{~K}$ which is well below the melting point of methyl-dialanine. For the present oven temperatures we expect no significant thermal decomposition of the molecules which is also confirmed by virtually identical fragmentation patterns in the electron ionization mass spectra recorded at $370 \mathrm{~K}$ and $400 \mathrm{~K}$.

\section{Computational Details}

To complement and interpret the experimental results, we have calculated the stability of the various fragments and molecules formed by means of the G4(MP2) method, ${ }^{26}$ the most recent of the Gx extrapolation methods. These quantum-thermodynamic schemes are believed to yield results close to 'chemical accuracy' $(2-3 \mathrm{kcal} / \mathrm{mol})$. The reaction thresholds have been obtained from the difference between all ground state energies of the reaction products (anion 
and neutral fragments) and reactants (the parent molecule). Further, HOMO and the LUMO energies of methyl-dialanine have been calculated using the outer-valence Green's function method $^{27,28}$ in conjunction with the $6-31++\mathrm{G}(\mathrm{d}, \mathrm{p})$ basis set. ${ }^{29,30}$ For the computation of the dipole moment of methyl-dialanine the B3LYP density functional ${ }^{31,32}$ and the aug-cc-pVTZ basis set $^{33}$ have been employed.

All quantum chemical calculations have been performed using the Gaussian 09 software. ${ }^{34}$

\section{Results and Discussion}

The ion efficiency curves of 11 anions from dissociative electron attachment to methyldialanine are shown in Figures 2 and 3, with the possible chemical compositions of these fragment anions and the position of their resonances listed in Table I. There is no evidence of a long-lived molecular anion, analogous to what has been found for native dialanine. ${ }^{19-22}$ The HOMO-LUMO gap is $9.0 \mathrm{eV}$ according to the EPT/6-31++G(d,p) model chemistry; the HOMO and LUMO energies are $-8.346 \mathrm{eV}$ and $0.663 \mathrm{eV}$, respectively. These orbitals are shown in Fig. 4. In order to display the in-plane and out-of-plane character of these orbitals, the molecular backbone in this figure was rotated to a near-planar configuration. The highest densities of the sigma-type HOMO are in the bonds belonging to the amide group and on the amino group (right side of Figure 4). The $\pi$-type LUMO resides on the opposite side of the molecule, above and below the plane of the ester group (left side of Figure 4). The total dipole moment of methyl-dialanine is 2.21 Debye. This is substantially lower than the one of native dialanine (between 4.17 D and 5.01 D for the three lowest optimized structures of dialanine ${ }^{19}$ ) and close to the limit to form a dipole bound state of the anion. ${ }^{35}$ Previously a dipole bound state (DBS) in amino acids was considered to act as doorway state ${ }^{36}$ for dissociation into (M$\mathrm{H})^{-}+\mathrm{H}$ by coupling of the DBS with the dissociative $\sigma^{*}(\mathrm{OH})$ state of the carboxyl group. ${ }^{35}$

One abundant fragment ion in DEA experiments with methyl-dialanine is assigned to the dehydrogenated parent anion, $(\mathrm{M}-\mathrm{H})^{-}, \mathrm{C}_{7} \mathrm{H}_{13} \mathrm{~N}_{2} \mathrm{O}_{3}{ }^{-}$, showing a low-energy feature with a threshold at $\sim 1.4 \mathrm{eV}$ and peaking at $2.4 \mathrm{eV}$ (see Fig. 2a and Table I). Figure 5 shows a comparison of $(\mathrm{M}-\mathrm{H})^{-}$for methylated and native dialanine. ${ }^{20}$ The latter shows two features peaking at 0.81 and $1.17 \mathrm{eV}$, i.e. resonances are obtained at considerable different energies compared to here. In our previous studies with native dialanine ${ }^{20}$ we derived by comparison of measured collision-induced decay spectra with dissociation trajectories of $(\mathrm{M}-\mathrm{H})^{-}$in molecular dynamics (MD)-simulations, that the formation of this fragment anion proceeds through abstraction of an hydrogen atom from the amide and carboxyl groups, leading to the 
two resonances at low electron energies. The first resonance shows a threshold at around 0.6 eV.

While the disappearance of the $1.17 \mathrm{eV}$ resonance accompanied by loss of the hydrogen atom from the carboxyl group is expected for methylated dialanine due to 'blocking' of this position by the methyl group, we note that surprisingly also the resonance at $0.81 \mathrm{eV}$ accompanied by loss of the hydrogen from the amide group is not present any more in the $(\mathrm{M}-\mathrm{H})^{-}$ion yield (although still a possible 'open' site for H-loss). In order to shed light on this observation we have performed quantum chemical calculations on the threshold energies for the dehydrogenated parent anion for methylated dialanine as a function of the initial site of $\mathrm{H}$ loss. The corresponding results are presented in Table II and the optimized structures for some of the $(\mathrm{M}-\mathrm{H})^{-}$isomers investigated are shown in Figures 1b)-1d). The reaction thresholds are obtained as the difference between the ground-state energies of the products and reactants. For energies close to the first resonance observed at $2.4 \mathrm{eV}$, initial loss of the hydrogen from the amide group is energetically accessible with a threshold at about $\sim 1.1 \mathrm{eV}$. It should be noted that after loss of hydrogen from the amino group also the amide isomer may form subsequently by proton transfer from the amide to the amino group during optimization which leads to the same threshold value of $1.12 \mathrm{eV}$. In contrast, the threshold for loss of the hydrogen from the amino group without subsequent proton transfer is substantially higher $(\sim 2.5 \mathrm{eV})$. The value obtained for $\mathrm{H}$-loss from $\mathrm{CH}_{3}$ at the carboxyl site is $2.84 \mathrm{eV}$, i.e. $1.7 \mathrm{eV}$ higher than for $\mathrm{H}$-loss from the amide group. Therefore, $\mathrm{H}$-loss from the amino group as well as $\mathrm{CH}_{3}$ at the carboxyl site will not contribute to the feature peaking at $2.4 \mathrm{eV}$. Comparing now the threshold for H-loss from the amide group for methyl-dialanine and dialanine we observe experimentally a shift of $\sim 0.8 \mathrm{eV}$ which leads as a consequence to the disappearance of the resonance at $0.81 \mathrm{eV}$. This difference in threshold can only be explained by methylation of the carboxyl group that shifts the threshold to higher energies, since the methylated fragment anion is less stable. For the other carbon sites in the methylated dialanine molecule the thresholds are between 1.66 and $3.24 \mathrm{eV}$, i.e. similar to native dialanine (ranging from 1.56 to $3.42 \mathrm{eV}$ ) although the individual values also change upon methylation (see Table 2). For H-loss from the carbon atom close to the central amide group a threshold of $1.66 \mathrm{eV}$ is observed, which is close to the threshold for H-loss from the amide group, i.e. the former site may also be involved in the $2.4 \mathrm{eV}$ resonance of $(\mathrm{M}-\mathrm{H})^{-}$. At this stage it is interesting to mention that in earlier DEA studies partial methylation was used to identify site selective Hloss from a biomolecule. However, studies with the pyrimidines (thymine/uracil), ${ }^{37}$ purines (adenine), ${ }^{38}$ and amino acids (glycine), ${ }^{8,39}$ indicated no apparent shift in the resonance 
thresholds and/or maximum of H-loss channels involving other sites than the methylated one. This is in strong contrast to the peptide studied presently, where a small shift of the threshold energy due to the methylation strongly alters the apparent anion efficiency curve.

We note that previously also partially deuterated molecules were used to identify selectivity in bond cleavage processes upon DEA to biomolecules. For example, in the case of thymine partial deuteration was used to distinguish between different isomers of $(\mathrm{M}-\mathrm{H})^{-40}$ as well as to determine the site of $\mathrm{H}^{-}$formation ${ }^{41}$ formed by cleavage of either nitrogenhydrogen or carbon-hydrogen bonds. However, the resulting ion yield of $(\mathrm{M}-\mathrm{H})^{-}$and $\mathrm{H}^{-}$of the partially deuterated compound remained virtually identical to the undeuterated molecule, ${ }^{40,41}$ i.e., the secondary isotope effect was negligible which can be also expected for DEA to partially deuterated dialanine.

The dehydrogenated methyl-dialanine parent anion shows in addition a weak contribution at $5.4 \mathrm{eV}$ (see Fig. 2a and Table I). Due to the fact that the incoming electron has already an energy far above the threshold of the different dissociation channels yielding (M$\mathrm{H})^{-}$(also from carbon sites), the deposited excess energy may also be sufficient to induce the decay into other fragments via a unimolecular decomposition of the dehydrogenated parent anion. However, in the case of native dialanine the high energy resonance was only observable on shorter timescales than available in the present experiment, i.e. no high energy resonance was observed with the current setup used (see Figure 5). ${ }^{20}$ In the present study the cross section for the loss of hydrogen at higher energies may be enhanced by the presence of another methyl group in the molecule which allows the detection of the high energy resonance. In addition, the shift of the threshold for the methylated molecule implies less excess energy in $(\mathrm{M}-\mathrm{H})^{-}$formed at this electron energy. Thus $(\mathrm{M}-\mathrm{H})^{-}$representing an intermediate in a sequential dissociation process may be formed more abundantly in favour of dissociation products. For example, we note that the additional loss of COO is not observed here within the detection limit of the apparatus, while $(\mathrm{M}-\mathrm{COOH})^{-}$was an abundant product anion in dialanine formed at $5.3 \mathrm{eV} .{ }^{19}$

The fragment ion at $143 \mathrm{u}$ (see Fig. 2b) is either formed via loss of a neutral methoxy radical $\left(\mathrm{OCH}_{3}\right)$ or neutral methylamine $\left(\mathrm{NH}_{2} \mathrm{CH}_{3}\right)$ from the TNI. For native dialanine an abundant $\sim 0 \mathrm{eV}$ resonance was ascribed to formation of $\left(\mathrm{M}-\mathrm{NH}_{3}\right)^{-}$while a much weaker resonance at $5.1 \mathrm{eV}$ was assigned to $(\mathrm{M}-\mathrm{OH})^{-}$. For the methylated species the resonance peaks are located at slightly higher electron energies, i.e. located at 0.4, 1.8 and $6.0 \mathrm{eV}$ (Table I and Figure 2b). Moreover, all three resonances show similar intensity, in contrast to native dialanine. As mentioned in Ref. 19 the low energy peak may also arise from thermal 
activation, which is suppressed in the present measurement due the lower evaporation temperature used.

The $141 \mathrm{u}$ anion yield is due to the loss of $\mathrm{CH}_{3}$ and $\mathrm{H}_{2} \mathrm{O}$ molecules from methyldialanine upon DEA and assigned to $\left(\mathrm{M}-\mathrm{CH}_{3}-\mathrm{H}_{2} \mathrm{O}\right)^{-}$. It shows three resonance features at 1.8, 5.9 and $8.3 \mathrm{eV}$ (Fig. 2d and Table I). The additional loss of a water molecule from the dehydrogenated dialanine has been confirmed recently in DEA studies. ${ }^{19}$ The intensity ratios of the resonances observed in the anion yield one mass above (142 u) match very well the natural abundance of the isotopic contributions of ${ }^{13} \mathrm{C},{ }^{15} \mathrm{~N}$ and ${ }^{18} \mathrm{O}(\sim 8 \%)$, i.e. no loss of methanol $\left(\mathrm{CH}_{3} \mathrm{OH}\right)$ is observed here. This is in contrast to native dialanine where the analogous fragmentation channel with loss of $\mathrm{H}_{2} \mathrm{O}$ was observed in a resonance at $8.9 \mathrm{eV}$ (onset $\sim 6.8 \mathrm{eV}$ ), i.e. this fragmentation channel becomes blocked by methylation of the dipeptide.

The low intensity anion efficiency curve of the fragment at $114 \mathrm{u}$ is shown in Fig. 2e. This mass corresponds to the loss of a neutral $\mathrm{HCOOCH}_{3}$, which is interesting to note with respect to the analogous weak fragmentation pathway in native dialanine, the loss of $\mathrm{HCOOH} .{ }^{22}$ In contrast, the anion one mass above $\left(\mathrm{M}-\mathrm{COOCH}_{3}\right)^{-}$is not observed within the detection limit of the present apparatus. This is in contrast to dialanine where the analogous channel $(\mathrm{M}-\mathrm{COOH})^{-}$was observed abundantly at energies $>4 \mathrm{eV}$. We have also calculated the threshold value for the $\left(\mathrm{M}-\mathrm{HCOOCH}_{3}\right)^{-}$anion and obtained a value of $0.6 \mathrm{eV}$ for removal of $\mathrm{COOCH}_{3}$ and the additional $\mathrm{H}$-loss from the amide group. $\mathrm{H}$-loss from the carbon sites in the immediate vicinity to the methylated carboxyl group results either in a higher threshold value (2.5 eV; for H-loss from adjacent carbon atom) or an unstable fragment anion with negative electron affinity (H-loss from nearby methyl group). The threshold value of $0.6 \mathrm{eV}$ matches well with the onset of the second resonance at $1.4 \mathrm{eV}$ obtained experimentally (see Fig. 2e). We ascribe therefore the first resonance at $\sim 0.4 \mathrm{eV}$ to an impurity. Another relevant anionic fragment is observed at $102 \mathrm{u}$ (Fig. 2f) and is tentatively assigned to $\mathrm{C}_{4} \mathrm{H}_{8} \mathrm{NO}_{2}{ }^{-}$ (which corresponds to the structure of methylated alanine undergone loss of a hydrogen atom), with just one resonance peaking at $5.3 \mathrm{eV}$. In the DEA studies with native dialanine the fragment anion corresponding to dehydrogenated alanine showed in addition a resonance close to $1.7 \mathrm{eV}$ which was tentatively assigned to an impurity of the sample by alanine monomers. ${ }^{19,22}$ The present results confirm this previous assignment within the detection limit of the apparatus. The fragments observed at 87 and $72 \mathrm{u}$ (Fig. 3a and b) are attributed to $\mathrm{C}_{3} \mathrm{H}_{7} \mathrm{~N}_{2} \mathrm{O}^{-}$and $\mathrm{C}_{3} \mathrm{H}_{4} \mathrm{O}_{2}{ }^{-}$, respectively, following the same assignment in DEA to dialanine because the methylated carboxyl group is cleaved as neutral fragment. ${ }^{20}$ The peaks positions 
listed in Table I are in very good agreement with those from Ref. 19. Such anion formation was explained in terms of an indirect mechanism for the $\mathrm{N}-\mathrm{C}_{\alpha}$ bond cleavage and has been supported by theoretical calculations. ${ }^{42}$ Briefly, regarding the $87 \mathrm{u}$ fragment, formation of the central carboxyl $\pi_{\mathrm{C}=\mathrm{O}} *$ anion diabatically couples with the dissociative $\sigma_{\mathrm{N}-\mathrm{Ca}}{ }^{*}$ state, making the reaction channel available for electrons at $\sim 2 \mathrm{eV}$. This is in excellent agreement with the lowest energy resonance at $1.8 \mathrm{eV}$ (Table I). However, as far as the high energy resonances are concerned, and bearing in mind that their intensities are much weaker than the one at 1.8 $\mathrm{eV}$, direct initial electron occupation of a repulsive $\sigma^{*}$ orbital may explain the formation of the high energy resonance at $5.1 \mathrm{eV}$ and $6.8 \mathrm{eV}$ for 87 and $72 \mathrm{u}$.

The anion efficiency curves as a function of the incident electron energy for fragments below $72 \mathrm{u}$ are shown Fig. 3c - 3e, with their species assignment and resonance positions listed in Table I. The fragment at $59 \mathrm{u}$ is due to $\mathrm{C}_{2} \mathrm{H}_{3} \mathrm{O}_{2}{ }^{-}$and shows only one resonance at 5.4 $\mathrm{eV}$ (Fig. 3c and Table I). The structure of such an anion is unknown, however it may correspond to the acetyloxyl anion $\mathrm{CH}_{3} \mathrm{COO}^{-}$or the $\mathrm{CH}_{2}=\mathrm{C}(\mathrm{OH}) \mathrm{O}$ anion. ${ }^{43}$ If we take the electron affinities of these two neutral molecules as 3.25 and $1.8 \mathrm{eV}^{43}$ and the standard bond dissociation energy for $\mathrm{C}-\mathrm{C}$ as $3.6 \mathrm{eV}$, we obtain threshold energies of 0.35 and $1.8 \mathrm{eV}$, respectively. Such values are well below the experimental threshold at $\sim 4.6 \mathrm{eV}$, meaning that such anion formation does not occur via low-lying electronic states of the anion and must be due to more complicated rearrangement reactions.

Figure $3 \mathrm{~d}$ and $3 \mathrm{e}$ show the yields of the fragment anions due to signals at 17 and $16 \mathrm{u}$. These are assigned to $\mathrm{OH}^{-}$and $\mathrm{O}^{-} / \mathrm{NH}_{2}^{-}$, with the former showing a considerable strong resonance at $0.4 \mathrm{eV}$ electron energy and a very weak contribution at $6.7 \mathrm{eV}$ (Table I). Such anion formation requires the breaking of a $\mathrm{C}=\mathrm{O}$ and $\mathrm{C}-\mathrm{H}$ bonds followed by rearrangement, where such a concerted mechanism is remarkable at low incident electron energies. As far as $\mathrm{O}^{-}$is concerned, the low energy resonance $(0.5 \mathrm{eV})$ may be attributed to an unknown contamination, whereas the high energy resonances are from the methyl-dialanine, which may also comprise contributions from the isobaric anion $\mathrm{NH}_{2}-9,44$ Comparing the resonance profile of the $16 \mathrm{u}$ anion (Fig. 3), and that from dialanine, ${ }^{19}$ we observe that the contribution at $6 \mathrm{eV}$ is due to $\mathrm{NH}_{2}^{-}$whereas the others (Table I) are preferentially due to the isobaric anion $\mathrm{O}^{-}$.

\section{Conclusion}

In the present DEA study on methyl-dialanine anion efficiency curves for 11 negatively charged fragments measured in the electron energy range of $0-15 \mathrm{eV}$ have been analysed. The dehydrogenated parent anion is an abundant fragment anion formed preferentially at the 
electron energy of $\sim 2 \mathrm{eV}$. High-resolution measurements combined with quantum chemical calculations of the threshold energies for the different $(\mathrm{M}-\mathrm{H})^{-}$isomers show that $\mathrm{H}$-loss from the amide group or one carbon site in the TNI are the only operative reaction channels in the low-electron energy region. However, comparison with the $(\mathrm{M}-\mathrm{H})^{-}$ion yield for native dialanine shows a shift of the lowest-lying resonance by about $1.6 \mathrm{eV}$ towards higher energies. This result is a consequence of the methylation of the carboxyl group which leads to considerable shifts of all thresholds for H-loss upon methylation. The assignment of molecular structures to the anionic masses observed is in full agreement with previous assignment done for native dialanine.

Methylation of amino acids was proposed as a possibility to overcome the low volatility of the native species. ${ }^{35}$ Indeed, in the present study utilizing an electron monochromator the evaporation temperature was more than $40 \mathrm{~K}$ lower than used for native dialanine. However, particularly in view of the identification of site selective loss of hydrogen by low energy electron attachment the present study shows that methylation may significantly modify the thresholds of fragment anion formation. In this case the resulting resonance shapes and positions alter not only by the blocking of specific sites in the molecule but by the modified energetic as well.

\section{Acknowledgments}

This work has been supported by the Fonds zur Förderung der wissenschaftlichen Forschung (FWF, P22665), Wien, the European Commission, Brussels, via COST Action MP1002 programme Nanoscale Insights into Ion Beam Cancer Therapy (Nano-IBCT) and by the Austrian Ministry of Science BMWF as part of the UniInfrastrukturprogramm of the Research

Platform Scientific Computing at the University of Innsbruck.. FFS acknowledges the Portuguese Foundation for Science and Technology (FCT-MEC) for a post-doctoral grant SFRH/BPD/68979/2010 and together with PL-V partial funding from the research grant PEstOE/FIS/UI0068/2011. S. E. H. is funded by the Austrian Science Fund (FWF) DK+ project Computational Interdisciplinary Modelling, W 1227-N16. 


\section{References}

1. B. Boudaïffa, P. Cloutier, D. Hunting, M. A. Huels and L. Sanche, Science, 2000, 287, 1658.

2. I. Baccarelli, I. Bald, F. A. Gianturco, E. Illenberger and J. Kopyra, Phys. Rep., 2011, $508,1$.

3. E. Alizadeh and L. Sanche, Chem. Rev., 2012, 112, 5578.

4. J. Kopyra, Phys. Chem. Chem. Phys., 2012, 14, 8287 and references cited therein.

5. J. Berdys, I. Anusiewicz, P. Skurski and J. Simons, J. Am. Chem. Soc., 2004, 126, 6441.

6. S. Gohlke, A. Rosa, E. Illenberger, F. Brüning and M. A. Huels, J. Chem. Phys., 2002, 116, 10164.

7. S. Ptasińska, S. Denifl, A. Abedi, P. Scheier and T. D. Märk, Anal. Bioanal. Chem., 2003, 377, 1115.

8. Y. V. Vasil'ev, B. J. Figard, V. G. Voinov, D. F. Barofsky and M. L. Deinzer, J. Am. Chem. Soc., 2006, 128, 5506.

9. A. Mauracher, S. Denifl, A. Aleem, N. Wendt, F. Zappa, P. Cicman, M. Probst, T. D. Märk, P. Scheier, H. D. Flosadóttir, O. Ingólfsson and E. Illenberger, Phys. Chem. Chem. Phys., 2007, 9, 5680.

10. S. Ptasińska, S. Denifl, P. Candori, S. Matejcik, P. Scheier and T. D. Märk, Chem. Phys. Lett., 2005, 403, 107.

11. P. Papp, J. Urban, S. Matejcik, M. Stano and O. Ingólfsson, J. Chem. Phys., 2006, 125, 204301.

12. H. Abdoul-Carime and E. Illenberger, Chem. Phys. Lett., 2004, 397, 309.

13. P. Papp, P. Shchukin and S. Matejcik, J. Chem. Phys., 2010, 132, 014301.

14. J. Kocisek, P. Papp, P. Mach, Y. V. Vasil'ev, M. L. Deinzer and S. Matejcik, J. Phys. Chem. A, 2010, 114, 1677.

15. J. Kopyra, I. Szamrej, H. Abdoul-Carime, B. Farizon and M. Farizon, Phys. Chem. Chem. Phys., 2012, 14, 8000.

16. F. Ferreira da Silva, S. Denifl, T. D. Märk, A.M. Ellis and P. Scheier, J. Chem. Phys., 2010, 132, 214306.

17. F. Ferreira da Silva, P. Bartl, S. Denifl, T. D. Märk, A. M. Ellis and P. Scheier, ChemPhysChem, 2010, 11, 90.

18. S. Denifl, I. Mähr, F. Ferreira da Silva, F. Zappa, T. D. Märk and P. Scheier, Eur. Phys. J. D, 2009, 51, 73.

19. E. Alizadeh, D. Gschliesser, P. Bartl, M. Hager, A. Edtbauer, V. Vizcaino, A. Mauracher, M. Probst, T. D. Märk, S. Ptasińska, N.J. Mason, S. Denifl and P. Scheier, J. Chem. Phys., 2011, 134, 054305 and references therein.

20. D. Gschliesser, V. Vizcaino, M. Probst, P. Scheier and S. Denifl, Chem. Eur. J., 2012, 18, 4613.

21. M. V. Muftakhov and P. V. Shchukin, Phys. Chem. Chem. Phys., 2011, 13, 4600.

22. Y. V. Vasil'ev, B. J. Figard, J. Morré and M. L. Deinzer, J. Chem. Phys., 2009, 131, 044317.

23. F. Ferreira da Silva, M. Lança, D. Almeida, G. García and P. Limão-Vieira, Eur. Phys. J. D, 2012, 66, 78 .

24. D. Almeida, R. Antunes, G. Martins, S. Eden, F. Ferreira da Silva, Y. Nunes, G. Garcia and P. Limão-Vieira, Phys. Chem. Chem. Phys., 2011, 13, 15657.

25. P. Sulzer, A. Mauracher, S. Denifl, M. Probst, T. D. Märk, P. Scheier and E. Illenberger, Int. J. Mass Spectrom., 2007, 266, 138.

26. L. A. Curtiss, P. C. Redfern and K. Raghavachari, J. Chem. Phys., 2007, 127, 124105.

27. L. S. Cederbaum, J. Phys. B, 1975, 8, 290. 
28. J. V. Ortiz, J. Chem. Phys., 1988, 89, 6348.

29. R. Ditchfield, W. J. Hehre and J. A. Pople, J. Chem. Phys., 1971, 54, 724.

30. M. J. Frisch, J. A. Pople and J. S. Binkley, J. Chem. Phys., 1984, 80, 3265.

31. A. Becke, J. Chem. Phys., 1993, 98, 5648.

32. C. Lee, W. Yang and R. G. Parr, Phys. Rev. B, 1988, 37, 785.

33. T. H. Dunning, Jr., J. Chem. Phys., 1989, 90, 1007.

34. M. J. Frisch, G. W. Trucks, H. B. Schlegel, G. E. Scuseria, M. A. Robb, J. R. Cheeseman, G. Scalmani, V. Barone, B. Mennucci, G. A. Petersson, H. Nakatsuji, M. Caricato, X. Li, H. P. Hratchian, A. F. Izmaylov, J. Bloino, G. Zheng, J. L. Sonnenberg, M. Hada, M. Ehara, K. Toyota, R. Fukuda, J. Hasegawa, M. Ishida, T. Nakajima, Y. Honda, O. Kitao, H. Nakai, T. Vreven, J. A. Montgomery, Jr., J. E. Peralta, F. Ogliaro, M. Bearpark, J. J. Heyd, E. Brothers, K. N. Kudin, V. N. Staroverov, R. Kobayashi, J. Normand, K. Raghavachari, A. Rendell, J. C. Burant, S. S. Iyengar, J. Tomasi, M. Cossi, N. Rega, J. M. Millam, M. Klene, J. E. Knox, J. B. Cross, V. Bakken, C. Adamo, J. Jaramillo, R. Gomperts, R. E. Stratmann, O. Yazyev, A. J. Austin, R. Cammi, C. Pomelli, J. W. Ochterski, R. L. Martin, K. Morokuma, V. G. Zakrzewski, G. A. Voth, P. Salvador, J. J. Dannenberg, S. Dapprich, A. D. Daniels, O. Farkas, J. B. Foresman, J. V. Ortiz, J. Cioslowski and D. J. Fox, Gaussian 09 Revision A.1 (Gaussian, Inc., Wallingford, CT, 2009))

35. Y. V. Vasilev, B. J. Figard, D. F. Barofsky and M. L. Deinzer, Int. J. Mass Spect., 2007, 268, 106.

36. T. Sommerfeld, Phys. Chem. Chem. Phys., 2002, 4, 2511.

37. S. Ptasińska, S. Denifl, P. Scheier, E. Illenberger and T. D. Märk, Angew. Chem. Int. Ed., 2005, 44, 6941.

38. S. Denifl, P. Sulzer, D. Huber, F. Zappa, M. Probst, T. D. Märk, P. Scheier, N. Injan, J. Limtrakul, R. Abouaf and H. Dunet, Angew. Chem. Int. Ed., 2007, 46, 5238.

39. H. D. Flosadottir, S. Denifl, F. Zappa, N. Wendt, A. Mauracher, A. Bacher, H. Jonsson, T. D. Märk, P. Scheier and O. Ingolfsson, Angew. Chem. Int. Ed., 2007, 46, 8057.

40. H. Abdoul-Carime, S. Gohlke and E. Illenberger, Phys. Rev. Lett., 2004, 92, 168103.

41. S. Ptasińska, S. Denifl, V. Grill, T. D. Märk, E. Illenberger and P. Scheier, Phys. Rev. Lett., 2005, 95, 093201.

42. M. Sobczyk, I. Anusiewicz, J. Berdys-Kochanska, A. Sawicka, P. Skurski and J. Simons, J. Phys. Chem. A, 2005, 109, 250.

43. NIST Chemistry webbook: http://webbook.nist.gov/chemistry

44. T. Hamann, A. Edtbauer, F. Ferreira da Silva, S. Denifl, P. Scheier and P. Swiderek, Phys. Chem. Chem. Phys., 2011, 13, 12305. 
Table I - Mass, assignment of the anionic species and peak positions for the fragment ions formed upon DEA to methyl-dialanine.

\begin{tabular}{|c|c|c|c|c|c|c|c|c|c|c|}
\hline $\begin{array}{c}\text { Mass } \\
\text { (Dalton) }\end{array}$ & Species & \multicolumn{9}{|c|}{ Peak position $(\mathrm{eV})$} \\
\hline 173 & $(\mathrm{M}-\mathrm{H})^{-}$ & $\ldots$ & $\ldots$ & 2.4 & 5.4 & $\ldots$ & $\ldots$ & $\ldots$ & $\ldots$ & $\ldots$ \\
\hline 143 & $\left(\mathrm{M}-\mathrm{NH}_{2} \mathrm{CH}_{3}\right)^{-} /\left(\mathrm{M}-\mathrm{OCH}_{3}\right)$ & $0.4^{\mathrm{w}}$ & 1.8 & $\ldots$ & $\ldots$ & 6.0 & $\ldots$ & $\ldots$ & $\ldots$ & $\ldots$ \\
\hline 141 & $\left(\mathrm{M}-\mathrm{CH}_{3}-\mathrm{H}_{2} \mathrm{O}\right)^{-}$ & $\ldots$ & 1.8 & $\ldots$ & 5.9 & $\ldots$ & $\ldots$ & 8.3 & $\ldots$ & $\ldots$ \\
\hline 114 & $\left(\mathrm{M}-\mathrm{C}_{2} \mathrm{H}_{3} \mathrm{O}_{2}\right)^{-}$ & 0.4 & 1.4 & $\ldots$ & $\ldots$ & $\ldots$ & $\ldots$ & $\ldots$ & $\ldots$ & $\ldots$ \\
\hline 102 & $\mathrm{C}_{4} \mathrm{H}_{8} \mathrm{NO}_{2}^{-}$ & $\cdots$ & $\cdots$ & $\ldots$ & 5.3 & $\ldots$ & $\ldots$ & $\ldots$ & $\ldots$ & $\ldots$ \\
\hline 87 & $\mathrm{C}_{3} \mathrm{H}_{7} \mathrm{~N}_{2} \mathrm{O}^{-}$ & $\ldots$ & 1.8 & $\ldots$ & 5.1 & $\ldots$ & $\ldots$ & $\ldots$ & 9.5 & $\ldots$ \\
\hline 72 & $\mathrm{C}_{3} \mathrm{H}_{4} \mathrm{O}_{2}^{-}$ & $\ldots$ & 1.2 & $\ldots$ & $\ldots$ & 6.8 & $\ldots$ & $\ldots$ & $\ldots$ & $\ldots$ \\
\hline 59 & $\mathrm{C}_{2} \mathrm{H}_{3} \mathrm{O}_{2}^{-}$ & $\ldots$ & $\ldots$ & $\ldots$ & 5.4 & $\ldots$ & $\ldots$ & $\ldots$ & $\ldots$ & $\ldots$ \\
\hline 17 & $\mathrm{OH}^{-}$ & 0.4 & $\ldots$ & $\ldots$ & $\ldots$ & 6.7 & $\ldots$ & $\ldots$ & $\ldots$ & $\ldots$ \\
\hline 16 & $\mathrm{O}^{-} / \mathrm{NH}_{2}^{-}$ & 0.5 & $\ldots$ & $\ldots$ & 5.9 & $\ldots$ & 7.0 & $\ldots$ & 9.4 & 11.5 \\
\hline
\end{tabular}

${ }^{\mathrm{w}}$ means weak feature 
Table II. Threshold energies of the dehydrogenated parent anion of methyl-dialanine as a function of the initial site of $\mathrm{H}$ loss (marked as underlined) from G4(MP2) calculations.

\begin{tabular}{|c|c|c|c|}
\hline H-loss site & Anion & Threshold (eV) & $\begin{array}{c}\text { Threshold } \\
\text { Dialanine } \\
(\mathrm{eV})^{\S}\end{array}$ \\
\hline amide group & $\mathrm{NH}_{2} \mathrm{CH}\left(\mathrm{CH}_{3}\right) \mathrm{CONCH}\left(\mathrm{CH}_{3}\right) \mathrm{COOCH}_{3}^{-}$ & 1.12 & 0.8 \\
\hline \multirow[t]{2}{*}{ amino group } & $\mathrm{NH}_{2} \mathrm{CH}\left(\mathrm{CH}_{3}\right) \mathrm{CONCH}\left(\mathrm{CH}_{3}\right) \mathrm{COOCH}_{3}^{-}$ & $1.12^{*}$ & \\
\hline & $\underline{\mathrm{NHCH}}\left(\mathrm{CH}_{3}\right) \mathrm{CONHCH}\left(\mathrm{CH}_{3}\right) \mathrm{COOCH}_{3}^{-}$ & 2.51 & 2.13 \\
\hline carboxyl group & $\mathrm{NH}_{2} \mathrm{CH}\left(\mathrm{CH}_{3}\right) \mathrm{CONHCH}\left(\mathrm{CH}_{3}\right) \mathrm{COO}_{2} \mathrm{H}_{2}^{-}$ & 2.84 & 0.91 \\
\hline \multirow[t]{4}{*}{ carbon sites } & $\mathrm{NH}_{2} \mathrm{CH}\left(\mathrm{CH}_{2}\right) \mathrm{CONHCH}\left(\mathrm{CH}_{3}\right) \mathrm{COOCH}_{3}^{-}$ & 3.28 & 2.43 \\
\hline & $\mathrm{NH} 2 \underline{\mathrm{C}}\left(\mathrm{CH}_{3}\right) \mathrm{CONHCH}\left(\mathrm{CH}_{3}\right) \mathrm{COOCH}_{3}^{-}$ & 2.24 & 1.60 \\
\hline & $\mathrm{NH} 2 \mathrm{CH}\left(\mathrm{CH}_{3}\right) \mathrm{CONH} \underline{\mathrm{C}}\left(\mathrm{CH}_{3}\right) \mathrm{COOCH}_{3}^{-}$ & 1.66 & 2.13 \\
\hline & $\mathrm{NH} 2 \mathrm{CH}\left(\mathrm{CH}_{3}\right) \mathrm{CONHCH}\left(\underline{\mathrm{CH}}_{2}\right) \mathrm{COOCH}_{3}^{-}$ & 2.93 & 1.56 \\
\hline
\end{tabular}

*Proton transfer from the amide to the amino group occurs during optimization

${ }^{\S}$ Reference 20 




Figure 1. Optimized structure of neutral methyl-dialanine (top). H-loss from the amide, amine and methylated carboxyl groups (from left to right) are shown in the structures below, respectively. 

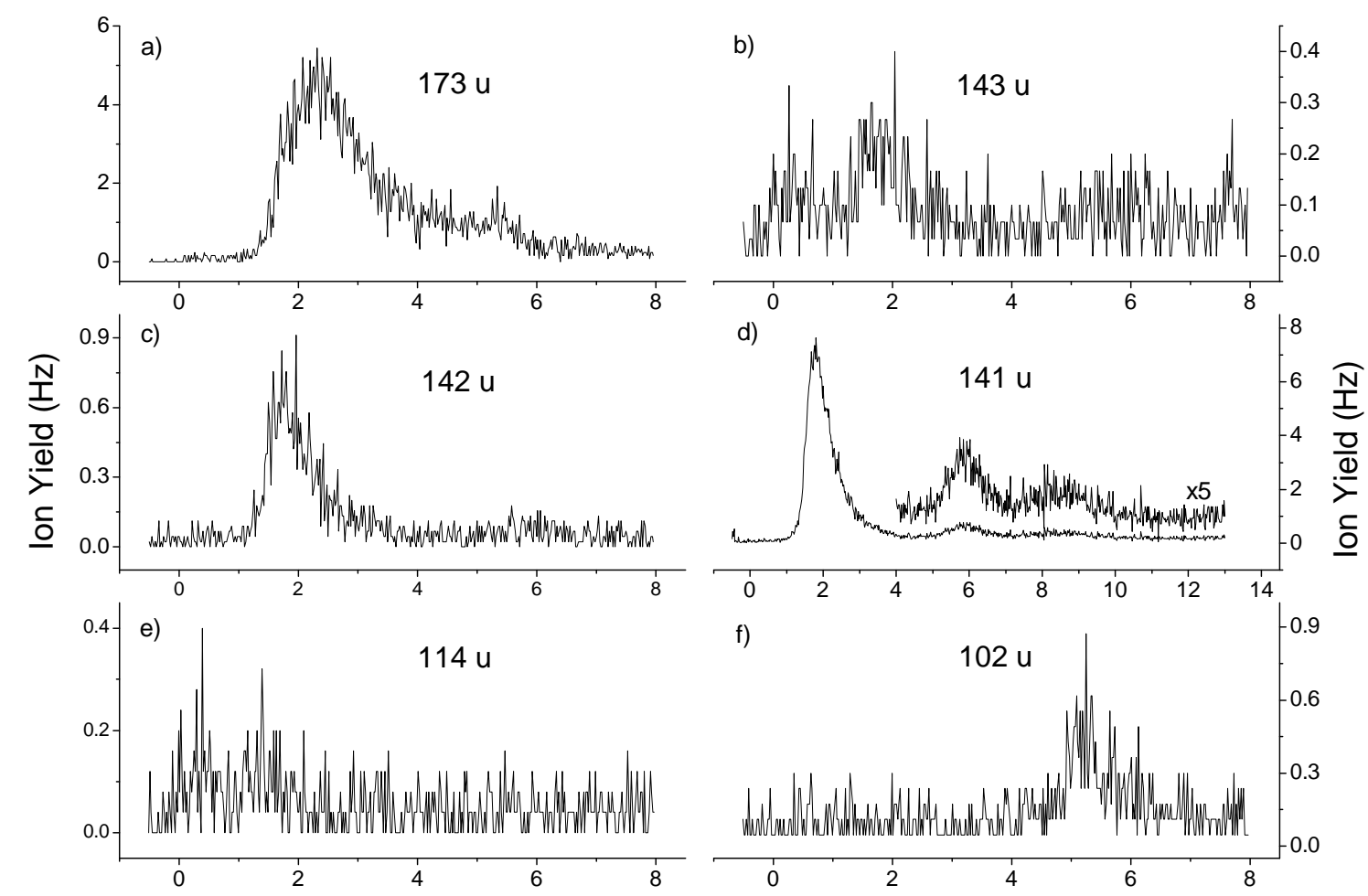

Electron energy $(\mathrm{eV})$

Figure. 2. Anion efficiency curves as a function of the incident electron energy for fragments between 173 and $102 \mathrm{u}$ formed upon DEA to methyl-dialanine. 


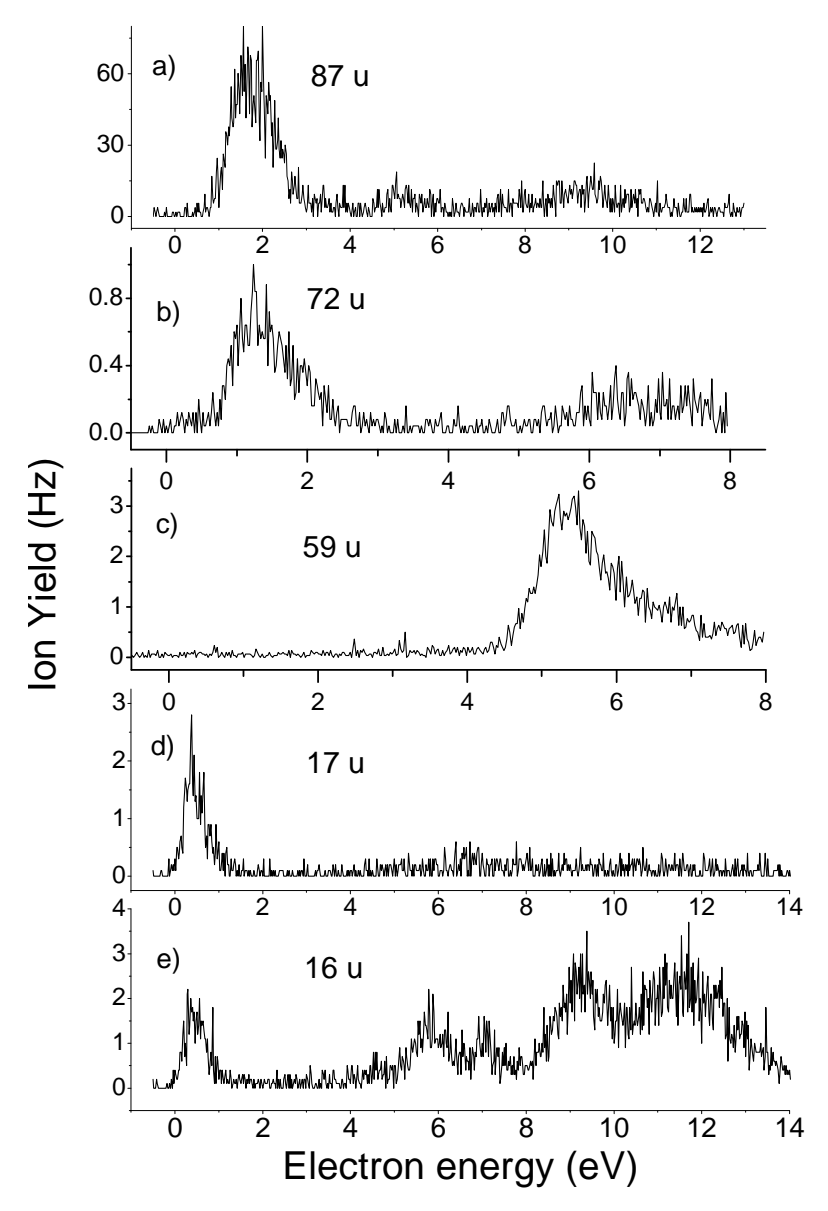

Figure 3. Anion efficiency curves as a function of the incident electron energy for fragments between 87 and $16 \mathrm{u}$ formed upon DEA to methyl-dialanine. 


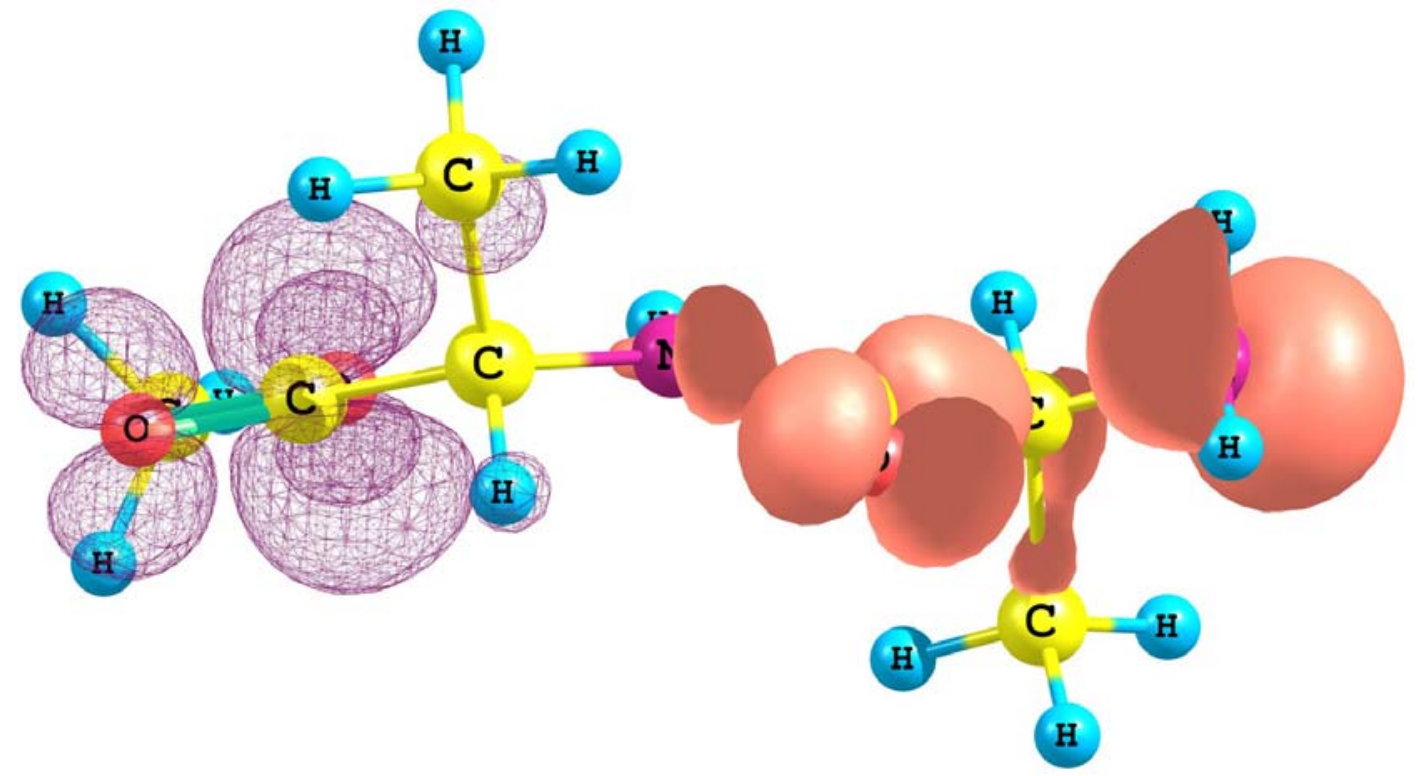

Figure. 4.

Highest occupied molecular orbital (HOMO: solid isosurfaces on the right side) and lowest unoccupied molecular orbital (LUMO: isosurface grids on the left side) of methyl-dialanine. Positive and negative values of the wavefunction are not distinguished. See text for explanations. 


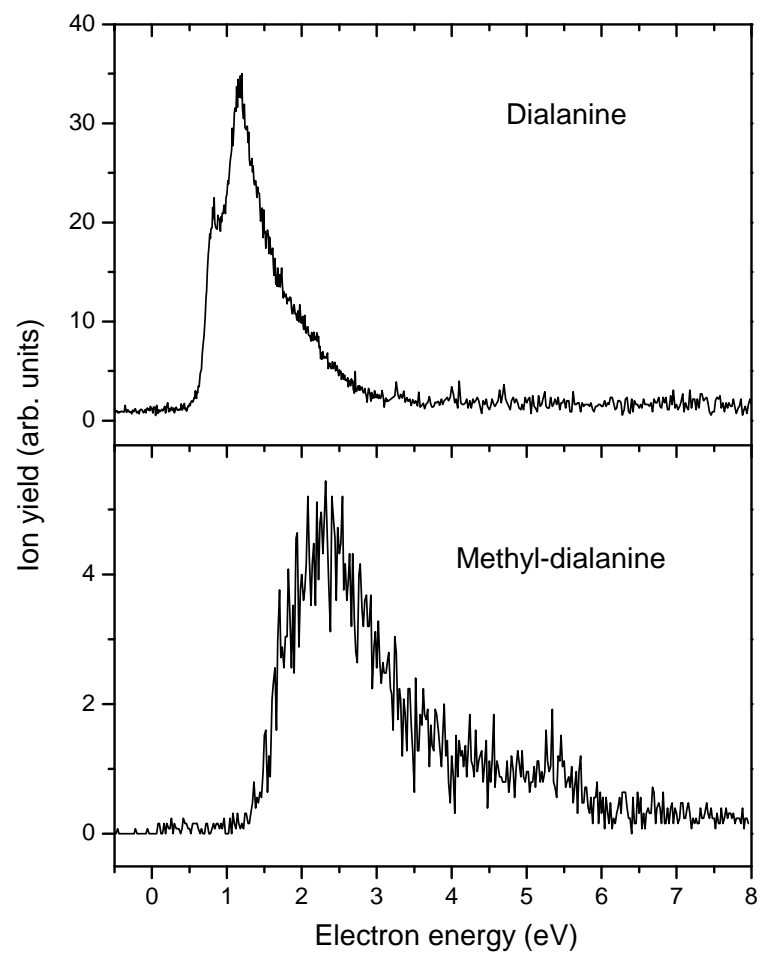

Figure 5: Comparison of the dehydrogenated parent anion for native dialanine (upper panel) and dialanine methylated at the carboxyl group (lower panel). 